\title{
Assessment on Observance of Essential Conditions of Marriage under Customary Marriage of Sidama, Southern Ethiopia
}

\author{
Fekadu Paulos Gujo \\ School of Law, Hawassa University, Hawassa, Ethiopia \\ Email: fadjopaul@gmail.com
}

How to cite this paper: Gujo, F. P. (2019). Assessment on Observance of Essential Conditions of Marriage under Customary Marriage of Sidama, Southern Ethiopia. Beijing Law Review, 10, 61-76.

https://doi.org/10.4236/blr.2019.101004

Received: December 16, 2018

Accepted: January 21, 2019

Published: January 24, 2019

Copyright $\odot 2019$ by author(s) and Scientific Research Publishing Inc. This work is licensed under the Creative Commons Attribution International License (CC BY 4.0).

http://creativecommons.org/licenses/by/4.0/

\section{(c) (i) Open Access}

\begin{abstract}
Both the FDRE Constitution, which has supremacy all over the country, and the Revised Constitution of the SNNPRS hinted the laws giving recognition to the marriage concluded under the systems of customary laws to be enacted. Accordingly, the House of Peoples' Representatives of the FDRE enacted the revised family code by revising provisions in Civil Code dealing with family matters. The council of the SNNPRS, on its part, enacted the family code applicable in the region. Under both family codes marriages concluded according to the custom are given recognition provided that the essential conditions set under them are observed. These essential conditions are consent, age, consanguinity, affinity, bigamy, judicial interdiction and observance of period of widowhood. This study, therefore, was conducted to evaluate whether the marriages concluded according to the custom of Sidama observe the essential conditions of marriage under the family code of the region. To this effect, the research employed combined method of interview and analysis of the statutes and secondary data on the customary marriage of Sidama. Besides, personal observations were also vital. The findings of the study revealed that the essential conditions of marriage under the family code are not observed while marriages are concluded according to the custom of Sidama, rendering the marriages susceptible to dissolution. Thus, all concerned organs are called to act towards the observance of the essential conditions of marriage while marriages are concluded according to the custom of Sidama as it majorly affects the rights of women and ultimately drags the nation into backwardness.
\end{abstract}

\section{Keywords}

Customary Marriage, Essential Conditions of Marriage, Family Code, Sidama 


\section{Introduction}

Marriage is a universal institution which is recognized (Family Law I Course Guide, National Open University of Nigeria, 2010) and practiced by all human societies since time immemorial (Kumo, 2016). It is a way to the family which, in turn, is very foundation of society and the state. The extent to which marriage is respected and protected is an important measure of healthy and civilized society. This principle is important not only for protecting the needs and interests of the spouses but also for the society and the state themselves, which have natural interest in assuring the subsistence of family as their basic unit.

It seems Ethiopia gained this awareness not later than the quarter of the second half of $20^{\text {th }}$ century when it enacted the Civil Code containing provisions dealing with family matters. This Civil Code recognized marriages concluded in civil, religious or customary forms (The Civil Code of the Empire of Ethiopia, 1960, Arts. 577-580). A quarter century later, Ethiopia enacted the Constitution, new of its kind, and the Southern Nations Nationalities and Peoples' Regional State (hereinafter, the SNNPRS), a member state of the Ethiopian federation in which the Sidama people inhibit, on its part, enacted the regional Constitution, which was later revised in 2001. These both Constitutions contain provisions hinting the law giving recognition to marriages concluded under the customary laws to be enacted (The FDRE Constitution, 1995, Art. 34 (4); The Revised Constitution of the SNNPRS, 2001, Art. 34 (4)). Accordingly, provisions under the Civil Code dealing with family matters repealed and the federal and regional governments enacted family laws applicable in their respective jurisdictions (The FDRE Revised Family Code, 2000, Art. 319 (1) (b) and The Family Code of the SNNPRS, 2004, Art. 334). The council of the SNNPRS, on its part, came up with the family code that recognizes marriages concluded according to the custom of community in which the spouses live or by the custom of the community to which they belong or to which one of them belongs (The Family Code of the SNNPRS, 2004, Art. 14) provided that the essential conditions of marriage are not violated (Ibid, Art. 36 (3)).

Sidama being one of the communities living in territorial jurisdiction where these laws apply is not an exception, the marriage concluded according to its custom to be recognized. The people in Sidama have been getting married from time immemorial. They do their marriage according to the rites of their customary law. In doing so, however, they are required to comply with the essential conditions of marriage under the family code. But, it has not yet been studied that the essential conditions of marriage under the family code are observed in marriages concluded according to the custom of Sidama.

With this in mind, this article tries to investigate the varieties of customary marriage conclusion in Sidama and the extent to which essential conditions of marriage under the family code are observed in each mode of customary marriage formation of Sidama. The article has both pragmatic and academic significance. Identifying the gap between the substantive legal requirements of mar- 
riage and the practice of the society and informing members of the society about the same are the practical social significance because it serves as an engine for social change. The academic significance of the article is that it ignites further research on the area and serves as a stepping stone as to why these provisions of the law are neglected by the society concerned. More specifically, it opens up a dialogue that whether such non observance is related with the society's level of development or the lack of legitimacy of the provisions by the society as they do not conform to their custom.

\section{The Meaning, Nature and Significance of Customary Marriage}

Before embarking on defining customary marriage of Sidama it is sensible to look at the customary marriage in general. Customary marriage is a marriage that is entered into according to the customs and traditions of societies. The question comes here is what the custom and tradition itself or themselves. Cambridge Advanced Learners' Dictionary defines custom as a way of behaving or a belief which has been established for a long time (Cambridge Advanced Learner's Dictionary-3rd ed.). On the other hand, it also defines tradition as a belief, principle or way of acting which people in a particular society or group have continued to follow for a long time, or all of these beliefs, etc. in a particular society or group (ibid). From the definition, one can understand that the term custom and tradition convey, more or less, similar meaning and can be used interchangeably. It is also equally important to say that customary marriage is a marriage concluded in a way that certain society has believed a marriage to be concluded or in a way it has actually been concluding for a long period of time.

The customary marriage of Sidama is a marriage which concluded in a way that Sidama people have been believed a marriage to be concluded or a way of actually concluding marriage in Sidama for longer period. In this way, even though there is denouncing on the part of custom that a marriage should not be concluded in a certain way still it may be taken as a customary marriage has been concluded if that way of acting has existed for a long time.

On the other hand, it is not simple task when it comes to defining customary marriage of Sidama. The Sidama people puts heavy focus on marriage. According to Sidama custom, marriage is the focus of existence. It is a point where all the members of a given community meet the departed, the living and those yet to be born (Muse, 1998). All the dimensions of time meet here and the whole drama of history is repeated, reviewed and revitalized. Marriage is drama in which everyone becomes an actor or actress and not just a spectator. Emphasizing on this, the Sidama elders say, marriage is a duty and requirement to arise the race and rhythm of life in which everyone must participate and anyone who does not participate in it is a curse to the community, a rebel and a law breaker; he is not only abnormal but also under-human (Ibid).

It is believed that the dead are reincarnated in part so that aspects of their personalities or physical characteristics are reborn in their descendants. A per- 
son who has no descendants in effect quenches the fire of life and becomes forever dead since his line of physical continuation is blocked. He, therefore, dies twice because nobody remembers him. To the opposite, when a person who has children dies physically, he will not really die because he leaves behind the offspring who represents him.

With regard to the nature of marriage, the union of a man and woman may not, in many cases, be permanent in Sidama (Abayineh, 1992). This is because, wife is free to desert her husband and conclude another marriage. Again if she is not satisfied in her subsequent marriage, she can still desert her second husband and marry another person without any limitation (Vecchiato, 1985). A woman may not only desert her husband and conclude another new marriage; but also her right to come back to her former husband without anytime limit and her personal qualities is reserved. The first husband of such wife, customarily, is under duty to accept such wife's reoffer in spite of his personal will and wish because it is believed that she is regretted about leaving her husband (Ibid).

The desertion of wife may come from the mismanagement of family by husband as head of family or from immaturity of wife (Muse, 1998). The husband is expected to provide all that satisfy the needs of the family. He is also required to take care of his wife and all in his household. If husband fails to do so, it amounts the mismanagement of family and may be aground for his wife to desert him. On the other hand, the wife may not be mature enough to weight and reach sound decision on essential matters. In such situations, she may prefer deserting her husband and concluding another marriage hoping that would bring better life.

The other thing worth mentioning is that bigamy is common among males. It is believed as index of social status so that it is not banned if not promoted. A person can marry many wives provided that he is confident of his means to maintain them and other related matters (Abayineh, 1992). Therefore, it can be argued that polygamous marriage, in its both forms (Muse, 1998), exists in customary marriage of Sidaama. Polygamy has two forms; polygyny and polyandry. The concept of polygyny denotes the union of one husband and two or more wives. Popularly this is called polygamy, but this is incorrect because polygamy denotes multiple males and applies to both polygyny and polyandry. The concept of polyandry, on the other hand, denotes the union of a woman with several men (Ibid). Though the woman, in Sidama custom, is not permitted to live together with different husbands at the same time and space, she can, however, do it at different time and space through desertion.

One may say marriage is nothing but legalization of sexual relations between a husband and wife. But the significance of marriage is something more than that. Indeed sexual relation in socially and legally recognized and approved ways is one of the significances of marriage.

Economy may be other reason that motivates one to marry. Traditionally, there is clear division of labor on the basis of sex. Wives perform many tasks which husband cannot, at least customarily. If husband does work traditionally 
considered women's, he will be dishonored. This makes the sexes interdependent cementing their need for each other.

Marriage through family is a means of getting necessary education concerning the knowledge of their custom, tradition, the origin of ascendants, and the genealogical purity of family and so on. The parents inculcate their outlook to their children so that they would follow the parents' suit. The mother is also required to educate her daughter concerning good management of household duties and discharging marital duties.

\section{Customary Marriage Practices in Sidama}

Practices of marriage differ from country to country and from one ethnic group to another with in a country depending on cultural and economic circumstances (Wolassa, 2016). It is also possible that ways of concluding customary marriage may vary within an ethnic group. Sidama could be a good example for this. In this regard, different studies on customary marriage of Sidama present four common types of marriage practices (Wolassa, 2016; Betana, 1991; Markos et al., 2012).

Apart from the four types of marriage practices mentioned above, there is marriage through Ragge in Sidama. Ragge is marrying a widow of diseased relative. Here after presented are, therefore, the five customary ways of concluding marriage in Sidama. These are: Buure aa, Aduulsha, Addawaana, Diiro, and Ragge.

\subsection{Buure Aa}

The term Buure aa literally means to hand over a girl after anointing a butter. That means, during the celebration of marriage, the bride's father anoints butter on hair of his daughter to bless her so that one way of giving his consent. This is the most widely accepted type of marriage because there is consent of two families and also impliedly the future spouses' consent assumed to be there (Betana, 1991; Abayineh, 1992).

Since there is full consent of the two respective families the girl's family advises her to stay with her first husband except some abnormal cases like having bad habits of stealing another person's property or unwilling to work and thereby being poor as this is disgraceful to her. Despite this, if the girl deserts her husband, her family bears responsibility to bring back to her former husband and reconcile the spouses by every attempt. Therefore, this type of marriage is the respected one and highly stable compared to other types of marriage.

\subsection{Aduulsha}

Aduulsha is literally interpreted as deceiving a girl to give her consent for marriage. After a long period of convincing a girl her future husband or intermediaries, a girl finally decides to the marriage without the knowledge of her family (Abayineh, 1992). This type of marriage can be done in two ways. The one pos- 
sibility is the engagement of two future spouses by meeting somewhere like traditional dancing place or school and they determine to marry each other (Markos et al., 2012). The other possibility is that the girl may not know her future husband but an intermediary may deceive a girl by telling his positive sides with much exaggeration. This time the girl becomes blind to foresee the consequences that would follow and gives her consent (Abayineh, 1992). Thus, the term aduulsha squarely fits to the latter case.

The reasons that lead a person to perform marriage without the consent of two respective families could be the impossibility of marriage through formal means because of the nature of their respective families, the non-coincidence of the boy's and his father's choice and existence of the common understanding and love affair between the two future spouses. As a result, they fix appropriate time and place to meet and go to the boy's family house. The boy's family may or may not know what was going on. If they do not know, the boy may send message in advance before reaching home so that they perform certain preparations ahead of time.

Meanwhile, the boy's family informs the whereabouts of the daughter to her family because they may be troubled as the girl may not tell them about her program. To avoid such trouble, however, the girl may use a customary sign of putting a hand kerchief together with a little number of coins on the bed of her parents which signifies her elopement together with her lover so that her family will get payment very soon (Abayineh, 1992).

\subsection{Addawaana}

The term addawaana denotes the consent of a girl for marriage by going to family of adult person without his knowledge and consent. Such girl by carrying a stick with her goes to the boy's family home. By the time she reaches home throws the stick to inside of home ascertaining the presence of boy's mother. Then, the mother invites her to come into the home (Betana, 1991). The reasons why such girl may be obliged to do such act could be that she may fall in love with such person who did not understand her or she may be unable to get a husband at proper time because of her conduct, lack of skill in food preparation and ugliness among others (Abayineh, 1992).

The boy's family after investigating the possible impediments of marriage, particularly the prohibitive degree, accepts her offer without considering other criteria as it is not customary to refuse the offer of such girl. In the event of refusal, the belief is that such person will not get any offspring, wealth or fortune (Muse, 1998). Therefore, the boy's family convinces him against his interest. If there, however, is prohibitive degree of relationship or some other impediments like her genealogical impurity, she may be ordered to go back or sent to her family. If her offer is accepted for they found no impediments, the usual process of notification, payment of bride wealth and seclusion continue (Ibid).

Since this type of marriage is shameful both to girl herself and her family (Betana, 1991), the amount of bride price is very less (Abayineh, 1992). Moreover, 
since the marriage is performed without the free will of husband, he may force such woman to leave his home for many reasons. By this time, such woman can marry any person without any restriction. If her first problem was lack of husband, she enjoyed a great freedom to marry a person one after another. This is because the demand of woman than that of a girl is high as the woman is considered as an asset and she does not ask anything except her maintenance. Therefore, anyone may welcome such woman for many reasons; particularly the poor person who could not get a girl for fear of bride wealth payment may prefer a woman until he becomes a man of wealth (Ibid).

\subsection{Diiro}

The term Diiro indicates abducting a girl for marriage against her consent. This act is done after careful investigation of common standards of marriage. After such investigation, the boy with his friends abducts the girl at some appropriate time and place like while she is fetching water, on her way to or from market or school (Betana, 1991).

The act of abducting a girl is not only a simple capturing of such girl by any one rather it has its own steps and process. The future husband should touch a girl first and then his friends assist him by carrying her through any means. Meanwhile, a big cry may arise by the girl to transmit the message to everyone for the need of help. As a result, a question of force will come into picture. Then the balance of power will determine the chance of success. If the boy is successful, he may take the girl some place to hide.

Immediately after arrival of home or even on the way the boy deflowers the girl. This is because if the girl is not deflowered those who are chasing may take her back if they are succeeded. Once she is deflowered, they do not take her back because she is no more virgin to be married and for payment of bride wealth (Ibid). After immediate deflowering, circumcision will follow if she is not circumcised previously. Then, she enters into seclusion (Vecchiato, 1985).

In the meantime, the boy's family will send a message to the girl's family concerning whereabouts of their daughter through one or two active youngsters. The messengers cautiously study the circumstance and inform to her family in the absence of adult male for fear of revenge.

Here one may ask about the response of community towards this very primitive and illegal act. In fact, many people have a negative attitude towards this act. Any reasonable people provide a defense to such helpless girl at the time of abduction. On the contrary, it is also common to find people who are reluctant to help such girl. This is due to the fact that kidnappers use force against anyone who tries to resist them since it is shameful to them to abandon the girl from their hands. Moreover, there are also some people who argue that "Seemo settu annite", i.e. a matured girl has no definite fiancé, the one who gets her by hook or crook becomes her husband (Abayineh, 1992). For this reason they become reluctant to extend help for such girl. 
The other point that should also be raised here is the reason why these young people engage in this costly act. There could be many reasons behind. First, the boy may be exhausted waiting of his father since it is the father who customarily betroths fiancée to his son. Second, the father's choice may not coincide to that of his son. The latter may spot at some girl other than betrothed by his father. Third, in spite of the will of the son, the girl's family may refuse to give consent for betrothal. Fourth, the young man may afraid to lose a girl to another boy specially when there is a rival. Fifth, false sense of power and competition to find a desirable partner encouraged by peer pressure motivates young man to engage in abduction. Perhaps his friends are all married and he is left alone without a woman, so the tendency is to prove that he is wanted. Finally, if the girl is good looking and admired by many suitors, she is going to be taken as a wife regardless of knowing each other deeply beyond her physically beauty (Interview with Kayeso Barasa, 2018).

As already shown above, the conflict between the two families is understandable. To reconcile this conflict, elders who are wise will be sent together with the boy's father to convince the girl's family and replace hostility into peace. Traditionally, these elders carry a sum of money by putting on a leaf and lay it in front of the girl's family. The rational of this is to award compensation for a faulty act that was done by their son during abduction. After a prolonged process of reconciliation, the two families come to the agreement and exorbitant amount of bride wealth will be fixed (Ibid).

As far as those who cooperated with abductor are concerned, they are free from any responsibility, at least customarily, once the one who led them is clearly identified.

\subsection{Ragge}

The term ragge indicates inheriting a widow of the deceased relative. A man may die leaving his wife, children and property behind. In these cases, it is customary to inherit such widow by the brother or other relative of the deceased. The reasons for this type of marriage in Sidama are to avoid feeling of orphanage among the children, to care and handle the property and to increase the lineage of the deceased person (Ibid, Interview).

If the relative or brother of the deceased does not want to inherit such widow, he has to slaughter a sheep and sprinkle the blood on the widow to bless her and so that to permit her to marry any person of her choice outside of the family (Interview with Tariku Dumo, 2018).

By way of summary it is worth mentioning similarities and differences of the above customary ways of marriage conclusion in Sidama. To begin with the similarities, these all are varieties but marriage conclusion under customary system of Sidama. Equal recognition is given for marriage concluded in either of these ways. The other similarity is there are some customary formalities to take place either before or after the conclusion of marriage. One of the formalities is payment of bride wealth. In cases where the families' of both spouses happen to 
know and agree the marriage to be concluded, the payment of bride wealth is effected before the marriage takes place. In other cases, however, bride wealth payment is to be made after marriage has been concluded as both or either of the families do not have information earlier.

When it comes to the difference, except in the first way of marriage conclusion; i.e., Buure aa, there would be no knowledge of the respective family about the plan of would be spouses. It is also in case of Buure aa only that bride wealth payment be effected prior to marriage conclusion. In case of Ragge, however, there is no such requirement of paying bride wealth as it is for the second time that this marriage is being concluded. Under Aduulsha way of marriage conclusion, would be husband may not even know his would be wife before. The vice versa is true in case of Diiro.

\section{Essential Conditions of Marriage and State of Their Observance}

The essential conditions of marriage that must be adhered in all forms of marriage are consent, capacity, consanguinity and affinity, bigamy and period of widowhood. Non-observance of these conditions brings civil and criminal sanctions. The civil sanction is the dissolution of marriage on the application of any interested person or the public prosecutor (The Family Code of the SNNPRS, 2004, Arts. 40-45) and the criminal sanctions are imprisonment and/or fine (The Criminal Code of the FDRE, 2004, Arts. 587, 647, 648 and 650).

\subsection{Consent}

Consent is the most essential element of concluding a valid marriage. A marriage to be valid, the parties have to give their free and full consent (The Family Code of the SNNPRS, 2004, Art. 16). And that consent must be expressed personally at the time of celebration of marriage. And hence, marriage through representation is prohibited (Ibid, Art. 22).

It should also be given free from violence (Ibid, Art. 24). If the consent of a spouse is obtained by violence, it brings defect in consent and renders the marriage voidable. Such marriage may subsequently be dissolved on application of a victim provided that the application for dissolution is made before six months from the cessation of such violence and in any case, not after two years from the conclusion of marriage (Ibid, Art, 44).

Likewise violence, error is another vice which makes consent defective. It is only, however, a fundamental error that constitutes vice of consent so as to amount dissolution of marriage. The family code restrictively enumerates only four kinds of error which constitutes fundamental error. These grounds of error are, error on identity of the spouse, where it is not a person with whom a victim intended to conclude marriage, error on the state of health of the spouse who is affected by a disease that does not heal or that can genetically be transmitted to descendants, error on the bodily conformation of the spouse who does not have the requisite sexual organ for the consummation of marriage and error on the 
behavior of the spouse who has the habit of performing sexual acts with person of the same sex (Ibid, Art. 23).

In customary marriage of Sidama, however, it is quite common that the consent of future spouses is not required. In most cases, contrary to the family code, the families of the spouses represent and give consent on behalf of future spouses. The rational of such representation is that the young person may not know about their future more than their parents. Though there is reverential fear towards parents, sometimes there is possibility of deviation from the consent of families. Such situation happens when male spouse abducts a girl against her will and the will of her or his family. In such cases, it is understandable that direct violence is exercised against the will of a girl.

In case of aduulsha, the intermediary may deceive a girl either telling the non-existing reputation of the future husband or by showing another individual as her future husband. In effect, error of identity of the intended spouse occurs. On the other hand, in cases of error of bodily conformation, marriage may be concluded permitting his wife impliedly to make sexual relations with other individual. The rational of such kind of marriage is the high consideration for children in Sidama culture. Even though a husband cannot be a biological father to the child born, he is still interested to have such child as his own (Interview with Oromo Oda, 2018).

\subsection{Capacity}

Under the family code, capacity is a condition precedent to conclude a valid marriage. Incapacity renders a marriage voidable. Such incapacity may arise from non-attainment of minimum marriageable age or judicial interdiction, per se (The Family Code of the SNNPRS, 2004, Arts. 17 (1) and 25 (1)).

In order to conclude a valid marriage, both male and female should attain a full age of 18 years except certain dispensation granted by the officer of the Justice Bureau of the region (Ibid, Art. 17 (2)). Moreover, the impediment of age is not absolute as the application for dissolution of such marriage ceases after the age required by law for marriage is satisfied. That is, defective marriage due to non-observance of minimum marriageable age becomes valid when a minor spouse attains majority (Ibid, Art. 40 (2)).

Whereas insanity is concerned, the judicially interdicted person cannot enter into marriage without being authorized by a court. If a person, disregarding this requirement, concludes marriage such marriage may be subject to dissolution (Ibid, Art. 43).

When we come to the age requirement provided under the family code, in most times, is not observed. Minority, in Sidama, is physical immaturity in quite contrary to what is provided under the family code. In fact, the age limit varies from locality to locality and economic position of the respective families. Furthermore, girls from poor and rich families may not get married at the same age. In latter case, there is fierce competition among male to marry her so that the chance of early marriage of such girl is very high. On the other hand, a boy from 
poor family may need a long time of preparation for bride wealth payment through his father and he may not get a chance of early marriage as a boy from rich family.

This age requirement may clearly be violated in marriage by abduction. It is also difficult to say the age requirement is observed in marriage by engagement of the respective families of the spouses. In fact, during engagement, the initial response of the girl's father is that his daughter has not attained marriageable age, but finally this defense set-aside if other customary requirements are met (Interview with Kayeso Barasa, 2018).

In Sidama, there is a bad belief rooted in the custom of Sidama. There is also a saying developed from such belief; i.e., "Meyaatinna busse anje diafidhino". A literal meaning of a saying is thereis no small pot and female; both could give service in spite of their size. Due to such deep-rooted belief, early marriage is prevalent in Sidama. That is obviously against the requirement of capacity under the family code.

Parents, in Sidaama, want their daughter to marry as early as the culture demands and perhaps they want to have a say in the matter. Accordingly, parents especially fathers, tend not to want their daughters to go to school because of their fear not to lose their daughters to a person they do not approve to marry her especially through abduction (Interview with Oromo Oda, 2018). There are many sayings that go with this belief of the people. One of such is "Ate rosi ayiiddaannikki mineeti" (Ibid, Interview). This is to mean your education is inside your husband s home or kitchen. And there is also another saying that is "Seennunna weese yannatenni hadhuro woyyanno" (Ibid). That means a female and enset need to go early. To get a girl is like watering a neighbor's tree; you have trouble and expenses in nurturing the plant but the profit goes to somebody else.

The prevalence of such early marriage denies girl children their right to education that they need for their personal development, preparation for adulthood and their effective contribution to the future wellbeing of the family and to the nation at large. If early marriage continues as it stands it could be said that it is depriving of girls their future educational advancement and subsequently the development in Sidama continues to be rhetoric and thus at stake.

As repeatedly said, the spouses involved in early marriage either through abduction or consent are barely able to think for themselves and hence the tendency is to end in poverty, inability to negotiate their childhood and adulthood in their relationship. They lack patience which eventually leads to bicker, intolerance and ultimately separation or divorce. This can be linked with problems identified during deliveries and underweight of babies due to lack of balanced diet and knowledge on the type of nutrition needed during pregnancy. Ultimately, the family cannot raise healthy children and mothers do not have enough knowledge to pass on to their children and thus intelligence could be affected. 
Moreover, women who marry early tend to deliver so many children, which is detrimental not only to their health and well-being but also it creates population problem, putting pressure on environment especially land for cultivation and building shelter that eventually results in poverty for the children added with no access to education and only option to depend on land for security.

\subsection{Consanguinity and Affinity}

Under the family code, marriage between consanguinal and affinal relatives is prohibited. The same goes true in case of illegitimate and adopted child. If those relatives married themselves in spite of these impediments, the marriage would be subject to dissolution on the application of any interested person, or the public prosecutor. Such marriage cannot subsequently be validated by the passage of time because the impediment of relationship is absolute and that it is so grave that it cannot be cured (The Family Code of the SNNPRS, 2004, Arts. 18, 19 and 41).

The bond of consanguinity arises in the direct line and in the collateral line. In the collateral line, the degree of relationship shall be calculated by counting seven generations in each line from common ancestor. Beyond the seventh degree, consanguinal relationship in the collateral line produces no effect whereas in the direct line, the relationship is not restricted by degrees. In other words, relatives in the direct line cannot marry each other.

The bond of affinity, however, has no effect beyond the third degree in collateral line. In the direct line, the affinal relationship is infinite as consanguinal relationship in the direct line. As regards to adoption, it creates the same effect as consanguinal and affinal relationship. In the event of non-observance of impediments of marriage arising out of consanguinity and affinity, the dissolution shall be ordered on the application of any interested person or the public prosecutor (Ibid).

In Sidama, there are three tribes, sub-tribes and clans (Abayineh, 1992). A marriage between members of the same clan (endogamous marriage) is prohibited. Therefore, the common form of marriage in Sidama is exogamous marriage (Ibid). That is, arrangement of marriage between members of different clans except few cases in clans of certain tribes and caste groups in such cases they practice endogamous marriage with observance of certain degree of consanguinal and affinal relationship.

On the other hand, marriage between a spouse and relatives of other spouse is prohibited. But the degree of affinity for such prohibition is not clear. Though affinity relationship creates impediment of marriage, it may cease after the death of a spouse particularly husband. In the event of the death of husband, such impediment of marriage may be violated since a wife may possibly be inherited by a relative of the deceased husband. In case of husband, however, it produces effect even after the dissolution marriage by any means (Interview with Kayeso Barasa, 2018). 
Finally, in the Sidama customary marriage, adoption produces no effect as impediment of marriage. Once the clan of adopted child is identified it brings no obstacle to marriage.

\subsection{Bigamy}

The family code provides monogamous marriage (The Family Code of the SNNPRS, 2004, Art. 21). The dissolution of bigamous marriage shall be ordered on the application of either of the former or the later spouse of the bigamous marriage or the public prosecutor. However, the court order of the dissolution of such marriage is possible where the former spouse of the bigamous marriage was alive at the time when such marriage is celebrated (Ibid, Art. 42). Logically, if the former spouse dies during the celebration or after the celebration of such marriage, but before application for dissolution, such marriage subsequently becomes valid and both marriages with legal effects. And this shows that bigamy is not absolute impediment of marriage. The family code prohibits not only a bigamous marriage but also irregular union being tied by the bond of a valid marriage.

Bigamous marriage is very common in customary marriage of Sidama. If the husband is able to afford their needs, he can marry as many wives as possible without any restriction. This can be done with or without the consent of former wife or wives. A poor wife has no bargaining power either to consent or refuse the act of her husband except her possibility of deserting her husband as a means.

A husband may be motivated to conclude a bigamous marriage for many reasons. In Sidama culture, child is considered as an asset than liability. If a woman bears no child, she may allow her husband to marry another woman and bear child from her. A wife's skill could also be another reason. If she is inactive in preparation of food and caring the children, the husband is tolerated to conclude another marriage. Lack of confidence by the husband on his wife on the ground that she may desert him could still be another reason as desertion of woman is simple and easy in Sidama customary marriage.

Having a number of wives is a sign of social status not a crime. The husband who has a number of wives divides his working and bed time among his wives. Often times, there is partiality of husband towards his later and possibly young wife; as a result, there is competition and jealousy among wives, specially the former and older ones.

\subsection{Period of Widowhood}

The family code puts a limitation that a woman whose marriage has become to an end cannot marry until one hundred and eighty days have lapsed (The Family Code of the SNNPRS, 2004, Art. 26 (1)). This prohibition, however, ceases if certain conditions are fulfilled. Firstly, it is if such woman gives birth to child after the dissolution of her first marriage. The rationale behind the prohibition of 
such subsequent marriage is to avoid the confusion of paternity. Therefore, if the court thinks that the confusion paternity will not arise because the woman has already given birth to child after the dissolution of her previous marriage, the woman may be dispensed from observing a period of widowhood. Secondly, if the woman remarries her former husband the confusion of paternity will not arise as the father could be the same person if she gives birth. Thirdly, the court may dispense the woman from observing a period of widowhood if it is proved by medical evidence that the woman is not pregnant or if it has ascertained that the woman is sterile or for any other reliable reasons (Ibid, Art. 26 (2)).

In customary marriage of Sidama, there is no clear situation that obliges a widow to wait until expiry of one hundred and eighty days or other time after the death of her husband. The woman whose marriage comes to an end can marry without any observance of the period of widowhood. There is no confusion of paternity since the first child that the wife would give birth to is considered as the child of former husband if the date of conception is identified. Sometimes, though not common, a woman may desert her husband or a marriage may dissolve by death and she marries another husband and gives birth to a child, such first child is considered as the child of her former husband irrespective of the date of conception (Interview with Kayeso Barasa, 2018).

Moreover, in case of widow inheritance by the brother or other relative of the deceased, she is not required to observe any period except some reasonable mourning period as the first child she gives birth is considered as the child of her former husband irrespective of the date of conception (Ibid, Interview).

\section{Conclusion and Recommendations}

\subsection{Conclusion}

Customary marriage of Sidama people is characterized by a union of a man and a woman permanently or temporarily. This marital union may be established through the consent of the two families, abduction of a girl, deceiving a girl or by sole will of a girl. In these cases, the consent of one party is not obviously there or is defective.

Moreover, in the case of marriage through consent of two families, the consent of future spouses may not be secured since their families do not ask their children's consent under the guise of customary belief that parents know what is better for their children. Presumably, the age requirement is also violated in such marriage.

Bigamous marriage is, on the other hand, taken as an index of social status. It, however, has a negative effect on the stability of marriage. Together with lack of consent, it leads to desertion of wife as one way of showing her grievances.

\subsection{Recommendations}

There are different social organizations within Sidama where women organize themselves for different activities. These social organizations could be used as a 
medium to discuss cultural issues and raise awareness. Some selected social organizations involving women could be used as medium for social change discussing the issues of abduction, early marriage, inheriting the widow of the deceased brother or relative, bigamy, etc. and reaffirm that standing together women can take their lives in their keeping.

In Sidama, there are formal and informal organizations that exist through which people express themselves. The formal organizations are the women associations at Kebele, Woreda and Zonal levels, saving and credit groups by Sidama Micro-finance Institution and Omo Micro-finance. The informal ones, on the other hand, include Edir, Ekub, Afansha and Church groups. These groups can be utilized as entry point to address cultural issues which are at the heart of low advancement of women and creating awareness through these groups to challenge the traditional structures and cultures that encourage early marriage, abduction, bigamy, inheriting a widow of the deceased brother or relative, etc. Women also need to understand why this culture is detrimental to their development as most of Sidama women are unaware to believe that this is a bad culture especially early marriage through consent of the two families.

The other main problem for the non-observance and failure of the law to be implemented properly is the lack of awareness of the society. The society has no awareness about the law. They believe that the law is only the customary law. Therefore, effort must be made to create awareness among the society about family law and the harmful effects of some traditional practices.

The law implementing bodies also contribute for the gap between the law and custom. For instance, the police are blamed of ignoring the provisions of the law and instead to their own decision for the reason that they themselves are the victims of traditional attitude. Therefore, sufficient training must be given to the law implementing bodies to reduce or eliminate the divorce of the law and practice.

The police should refuse the elders peacemaking initiative in cases of abduction and charge them as perpetrators in order to address the issue at community level and to put policy into practice. The police should also carefully examine the withdrawal of abduction cases by parents and charge them as well.

Educational status of women has its impact on the implementation of women's rights. Women's low educational status paves the way for the prevalence of the harmful traditional practice which blocks the society from observing the law. Therefore, special emphasis should be given to women's education to build their capacity and enable them to challenge harmful traditional practices.

\section{Acknowledgements}

The author's heartfelt and special thanks go to God for His love and provisions all the way through. He would also like to thank anonymous reviewers of this piece of article because had it not been for their constructive comments, it could not have this shape. The author alone is responsible for any blunders. 


\section{Conflicts of Interest}

The author declares no conflicts of interest regarding the publication of this paper.

\section{References}

(2008). Cambridge Advanced Learner's Dictionary (3rd ed.). Cambridge: Cambridge University Press.

Abayineh, A. (1992). Customary Marriage of Sidama People in Light of Civil Code. AAU.

Betana, H. (1991). Sidama: People and Culture (Amharic). Addis Ababa: Bole Printing Press.

Federal Democratic Republic of Ethiopia (1995). Constitution of the Federal Democratic Republic of Ethiopia (Proclamation No. 1/1995), Addis Ababa, Ethiopia.

Federal Democratic Republic of Ethiopia (2000). The Revised Family Code of the Federal Democratic Republic of Ethiopia (Proclamation No. 213/2000), Addis Ababa, Ethiopia.

Federal Democratic Republic of Ethiopia (2004). The Criminal Code of the Federal Democratic Republic of Ethiopia (Proclamation No. 414/2004), Addis Ababa, Ethiopia.

Interview with Kayeso Barasa (2018). Elder of the Chire Woreda of the Sidama Zone, SNNPR, Ethiopia.

Interview with Oromo Oda (2018).Elder of the Chire Woreda of the Sidama Zone, SNNPR, Ethiopia.

Interview with Tariku Dumo (2018). Elder of the Chire Woreda of the Sidama Zone, SNNPR, Ethiopia.

Markos, T., et al. (2012). The History and Culture of the Sidama Nation (Amharic).

Muse, Y. (1998). Traditional Marriage of Sidama People. AAU.

National Open University of Nigeria (2010). Family Law Course Guide. Lagos.

Southern Nations, Nationalities and Peoples' Regional State (2001). The Revised Constitution of the Southern Nations, Nationalities and Peoples' Regional State (Proclamation No. 35/2001). Hawassa, Ethiopia.

Southern Nations, Nationalities and Peoples' Regional State (2004). The Family Code of the Southern Nations, Nationalities and Peoples' Regional State (Proclamation No. 75/2004), Hawassa, Ethiopia.

The Empire of Ethiopia (1960). The Civil Code of the Empire of Ethiopia (Proclamation No. 165/1960), Addis Ababa, Ethiopia.

Vecchiato, N. (1985). Culture, Health and Socialism in Ethiopia: The Sidamo Case. Los Angeles: University of California.

Wolassa, L. K. (2016). The Sidama Nation: History, Culture and Political Economy. Scotts Valley, California: Create Space Independent Publishing Platform. 